\title{
Development and Validation of Leadership Skill Assessment Scale for Secondary School Principals
}

\author{
Catherine N. Elechi \\ Department of Educational Foundations, \\ Enugu State University of Science and Technology, \\ Enugu-Nigeria
}

Doi:10.5901/jesr.2013.v3n5p9

\begin{abstract}
This study was designed to develop and validate principals' Leadership Skill Assessment Scale. It is an instrumentation study. The sample for the study comprised all the secondary school principals in Enugu State. Two research questions guided the study. Data were collected using a draft copy of the Principals Leadership Skill Assessment Scale. The data were subjected to construct validation using factor analysis with varimax rotation and Cronbach Alpha( $\alpha)$. Results of data analysis reveal that out of the thirty six items subjected to construct validation, only thirtyone items had a minimum loading of up to 0.35 (acceptance level for factor loading according to Menedith, 1969) on the six factors extracted. Five items did not attain the minimum loading on any of the six factors. One item was loaded on factors 3 and 4 and was considered factorially complex and was discarded along side the other five items that did not attain the minimum loading of 0.35 on any of the six factors. Result of factor analysis also reveals that some factors have fewer than four items loaded on them. Because it is not easy to explain such factors, the four items were also discarded. Out of the thirty six items, a total of ten items (items 14, 21, 22, $24,27,28,32,33,34$ and 36) were dropped as invalid items. Test of internal consistency for the surviving twenty-six items reveal that the instrument has an internal consistency index of 0.958 . Based on the findings, the researcher recommends that measurement of principals leadership skill should constitute a regular practice of the Post Primary Schools Management Board especially now that a valid and reliable instrument for the exercise has been developed. The researcher further recommends that researchers in the field of leadership should adopt this instrument in situations that require a clear assessment of principals' leadership skills.
\end{abstract}

Keywords: Leadership, Validation, Reliability, Assessment, Instrumentation

\section{Introduction}

Leadership is a topical issue in education and school administration. According to Adesina (1992), it is the quality, which in theory signifies the ability of a person, or group of people to persuade others to act by inspiring them and making them believe in a proposed course of action. Leadership implies followership, which exists within an organizational context. As an aspect of influence process in an organization, leadership is both a process and a property. As a process, it involves the use of non-coercive influence but as a property, it is the set of characteristics attributed to someone who is perceived to use influence successfully (Moorhead and Griffin 2004). Although researchers in the field of administration conceive leadership from a varying theoretical and practical perspectives which range from skill to behaviour exchanges, it must be appreciated that their ideas tend to converge at a point where leadership could be generalized as the ability and readiness to inspire, guide, direct or manage others. Mschane and Vonglinow (2010) identified 
two dimensions of leadership - initiating structure and consideration. According to Mcshane and VonGhnow (2010) initiating structure refers to the leader's behaviour in delineating the relationship between himself and members of the work group, and in endeavouring to establish well defined patterns of organization, channels of communication and methods of procedure. On the other hand consideration implies the behaviour indicative of friendship, mutual trust, respect and warmth in the relationship between the leader and members of his staff.

Ajiboye (1990) rightfully pointed out that within the school system leadership does not exist for itself, rather it exists for the staff and students and its efficacy must be measured by the extent to which it contributes to teaching and learning. The effective leader should not only take steps to satisfy the psychological and sociological needs of the employees but also ensure that the entire school system functions as a whole. In order to achieve the objectives of education, secondary education needs effective and efficient leadership. Effective leadership is essentially characterized by smooth flow of information and efficacy in discharge of duties. These functions are the responsibilities of an effective leader through his effectiveness is very much influenced by subordinates.

In the past years especially with the creation of Enugu State, which catalyzed hurried appointment of school principals, the status of secondary education has begun to change. Inspite of the increasing support of state and federal government in the provision of instructional resources and trained personnel to secondary schools and also the unrelenting efforts of Parent Teacher Association (PTA) and other non-governmental agencies, in ensuring effective teaching and learning, the trend in job performance of teachers and the academic achievement of students have not improved. A number of administrative lapses have currently characterized secondary school administration especially in Enugu State. In fact, the degree of teacher redundancy, lateness to school, overt truancy, disruptive behaviours on the part of the students and the associated poor academic achievement go a long way to confirm the degenerating status of secondary education.

Although the current trends in secondary school management have been speculated to stem from the leadership styles of principals, such assumptions lack empirical backings. While it is also well acknowledged that issues pertaining to leadership in school administration have not been played down by researchers, it must be appreciated that the validity of most research findings in school administrative leadership have been inherently questionable. This is because of the paucity of a standard measuring instrument in the leadership skill domain.

While also the issue of leadership has been widely emphasized in school administration, the aspect that pertains to its measurement has not gained prominence in current research discourse. This makes it obviously impossible for researchers to carry out an intensive and reliable study in the field of leadership. Considering also the current inclusion of leadership skill as basis for appointment of principals by the Enugu State Post Primary Schools Management Board (PPSMB) (2004), one may wonder how this objective could be realized without a valid and reliable measuring instrument.

In view of the current emphasis on effective leadership and the acquisition of good leadership skill as a requisite for appointment and promotion of principals, it has become obviously necessary that a valid and reliable leadership skill Assessment Instrument be developed for researchers in the field of administrative leadership and also for effective screening of would be' or 'already appointed' principals. This will go a long way in improving not only research in school administration but also enhance the proposed programme on appointment, promotion and re-training of school principals PPSMB.

\section{Statement of the Problem}

The current high rate of administrative lapses in secondary schools, which manifest in staff redundancy, truancy and poor scholastic achievement on the part of the students are sources of distress to the education ministry and the entire public where investments on education need to be 
justified. Although the general consensus about these problems is that secondary schools lack good leaders who could co-ordinate both the human and material resources of the schools so adroitly towards the realization of the set objectives, it must be appreciated that the extent of acquisition of leadership skills among the school principals is merely speculated. This is true because, most studies on leadership were conducted without a valid and reliable measuring tool in that specific skill domain. According to Asike (1997), most researchers in the field of leadership had gone ahead to collect data on leader skills and behaviour using ordinarily face-validated tools.

In view of the fact that the psychometric attributes of the available instruments were not ascertained, it is quite obvious that whatever data collected with such an instrument and the conclusions derived from them are also questionable. In the same vein, if the on going proposal by the Enugu State PPSMB on screening of principals' leadership skills as basis for appointment, promotion and retraining is to be realized, there has to be a valid and reliable instrument for the measurement of such skills. This study is therefore faced with the problem of developing and validating a reliable and valid leadership skill assessment scale (LSAS) for secondary school principals.

\section{Purpose of the Study}

The purpose of this study is the develop and validate a Leadership Skill Assessment Scale (LSAS) for secondary school principals. Specifically this study is designed to:

a. develop a valid Leadership Skill Assessment Scale (LSAS)

b. determine the reliability of the LSAS

\section{Research Questions}

The following research questions guided this study:

1. How valid is the principals' Leadership Skill Assessment Scale in terms of its factor loading?

2. What is the reliability index of the principals' Leadership Skill Assessment Scale?

\section{Research Method}

The study is an instrumentation study. An instrumentation research is the type of research study that focuses on introduction of new or modified content, procedure, technologies or instruments of educational practice. The study was carried out in Enugu State of Nigeria. The population of the study comprised all the secondary school principals in Enugu State. These also comprised the sample since the population is not large. In generating the draft copy of the instrument, forty items were generated. This was to make provision for item mortality both at the preliminary assessment stage and during the main field work. It is a likert type scale scored on 4-point basis. The draft copy was face validated by four specialist. This was later administered to a sample of thirty principals for field test. Their responses were scored and subjected to factor analysis. Four items were dropped leaving a total of 36 items. The 36 items were used in the main field work. The 36 items that survived the validation exercise were also subjected to reliability assessment. Copies of the 36-item principals Leadership Assessment Scale were administered to all the principals used for the study.

Research question 1 was answered using factor analystic procedures (ie principal factors and normal varimax rotation). The cronbach alpha was used to answer research question 2.

\section{Results}

Results are presented in tables according to individual research questions. 


\subsection{Research Question 1}

How valid is the principals' Leadership Skill Assessment Scale in terms of its factor loadings?

For this research question, the thirty six items of the principals leadership skill assessment scale were subjected to construct validation procedures using principal component analysis with varimax rotation. Summary of the rotated factor loadings of the items is shown in table 1 .

Table 1: Varimax Rotated Factor Loadings of the items of LSAS

\begin{tabular}{|c|c|c|c|c|c|c|}
\hline Items & Factor 1 & Factor? & Factor 3 & Factor 4 & Factor 5 & Eactor 6 \\
\hline 1 & .72143 & .14680 & .13833 & -.20601 & -.24120 & .08971 \\
\hline 2 & .12622 & .83939 & -.09251 & -.02269 & -.14171 & .09136 \\
\hline 3 & 10775 & .84052 & -.02839 & -.22966 & .11083 & -.01902 \\
\hline 4 & .03563 & .06639 & .13911 & .02889 & .90754 & .09627 \\
\hline 5 & .88165 & .09638 & .02191 & -.11034 & -.03519 & .06881 \\
\hline 6 & .09247 & .90618 & -.00568 & -.00125 & .08644 & .09325 \\
\hline 7 & .87389 & .08868 & .21862 & .00418 & -.10277 & -.2476 \\
\hline 8 & .12255 & .88903 & -.08883 & -.00367 & -.08168 & .13701 \\
\hline 9 & .11292 & .05280 & .15259 & .12412 & .86201 & .09404 \\
\hline 10 & .19057 & .08260 & .87342 & .06355 & .17832 & -.06205 \\
\hline 11 & .84467 & .06938 & .21500 & .10114 & -.11953 & -11397 \\
\hline 12 & .04463 & .10348 & .90427 & .18512 & .10669 & .10274 \\
\hline 13 & .87662 & .08416 & .17508 & .03632 & -.04375 & -.04219 \\
\hline 14 & .23734 & .06329 & .10869 & .81173 & .19666 & .10430 \\
\hline 15 & .86158 & .10556 & .17850 & .03993 & .10215 & -.11646 \\
\hline 16 & .24342 & .12658 & .85040 & -.02506 & -.08546 & .01788 \\
\hline 17 & .24342 & .11092 & .85040 & -.06724 & -.02479 & -.14886 \\
\hline 18 & .05074 & .13447 & -.06149 & 20131 & .85571 & .02762 \\
\hline 19 & .22629 & .96700 & .03641 & .06075 & .05448 & .01332 \\
\hline 20 & .58291 & .22424 & 14131 & .03663 & -.00502 & -.13298 \\
\hline 21 & -.07631 & -.02109 & -.76536 & -.01392 & .06223 & -.00281 \\
\hline 22 & -.09534 & -.12284 & .13724 & -.24810 & -.54722 & .16512 \\
\hline 23 & .10669 & .10348 & .04463 & .18512 & .90427 & .10274 \\
\hline 24 & -.19616 & -.01658 & -.49771 & .16258 & 0.9822 & -.04010 \\
\hline 25 & .88903 & .12255 & -.08883 & -.00867 & -.08168 & .13701 \\
\hline 26 & .20263 & .06025 & .21451 & .04755 & .78818 & -.10395 \\
\hline 27 & -.11095 & -.03099 & .02790 & -.12153 & .07750 & -.84971 \\
\hline 28 & -.09110 & -.01872 & .18859 & -.67952 & -.07128 & -.14428 \\
\hline 29 & .22629 & .96700 & .03641 & .06075 & .05448 & .01332 \\
\hline 30 & .85040 & .11092 & .24342 & -.06724 & -.02479 & -.14886 \\
\hline 31 & .22629 & .96700 & .03641 & .06075 & .05448 & .01332 \\
\hline 32 & .14726 & .08535 & .45208 & .38649 & .08499 & -.07657 \\
\hline 33 & .09503 & -.00696 & .24617 & -.36606 & .29347 & .46679 \\
\hline 34 & -.05221 & .11412 & .13720 & .16008 & -.28452 & .38952 \\
\hline 35 & -.16380 & .04831 & -.08455 & -20731 & .68988 & -.00891 \\
\hline 36 & .05481 & .12475 & -.16281 & .03416 & -.06006 & .78315 \\
\hline
\end{tabular}

Summary of factor analysis presented in Table 1 reveals that six factors were extracted. Each factor has items loaded on it. As revealed in the Table only thirty-one items had a minimum 
loading of up to 0.35 (acceptance level for factor loading according to Meredith 1969) on the six factors. The items include items $1,2,3,4,5,6,7,8,9,10,11,12,13,14,15,16,17,18,19,20$, $21,22,23,24,25,26,27,28,29,30,31,32,33,34,35$, and 36 . Five items did not attain the minimum loading of up to 0.35 on any of the six factors. They are items 21, 22, 24, 27, and 28. One item (item 32) was loaded on factors 3 and 4 and was therefore considered factorially complex and was discarded along side the other five items that did no attain the minimum loading of 0.35 on any of the six factors. The table also reveals that some factors have fewer than four items loaded on them. They are factor 4 (item 14) and factor 6 (items 33, 34, and 36). According to Meredith (1969) it is not easy to explain such factors that have fewer than four items loaded on them. These four items (items 14, 33, 34 and 36) were also discarded.

In all therefore a total of ten items (item 14, 21, 22, 24, 27, 28, 32, 33, 34, and 36) were dropped as invalid items. Summary of factor loadings for the surviving twenty-six items is presented in Table 2.

Table 2: Summary of the Factor Loadings of the surviving twenty-six Items of the LSAS

\begin{tabular}{|c|c|c|c|c|c|}
\hline \multirow{2}{*}{ Factor } & \multicolumn{2}{|c|}{ Items } & \multirow{2}{*}{ Item Structure } & \multirow{2}{*}{ Loading } & \multirow{2}{*}{ Comm } \\
\hline & Draft & Validated & & & \\
\hline & 1 & 1 & Act without consulting your staff & .72143 & .66982 \\
\hline & 5 & 5 & Refuse to explain his actions & .88165 & .80523 \\
\hline & 7 & 7 & Make all class scheduling & .87389 & .83054 \\
\hline & 11 & 11 & $\begin{array}{l}\text { Keep records of defaulting teachers through } \\
\text { class records }\end{array}$ & .84467 & .80201 \\
\hline & 13 & 13 & Delegate responsibilities to deserving staff & .87662 & .81121 \\
\hline & 15 & 14 & Treat all members of staff as colleague & .86158 & .81091 \\
\hline & 20 & 19 & Use positive reinforcement to motivate staff & .58291 & .42909 \\
\hline & 25 & 21 & $\begin{array}{l}\text { Provide incentives to challenge staff } \\
\text { productivity }\end{array}$ & .88903 & .83874 \\
\hline & 30 & 24 & $\begin{array}{l}\text { Show interest in negotiation for better } \\
\text { condition for teachers }\end{array}$ & .85040 & .82203 \\
\hline & 2 & 2 & Insist on implementing changes & .83939 & .75801 \\
\hline & 3 & 3 & Are known for high expectations from staff & .84052 & .78428 \\
\hline & 6 & 6 & Insists on standard rules and regulations & .90618 & .84592 \\
\hline & 8 & 8 & Dominate the staff meeting & .88903 & .83874 \\
\hline & 19 & 18 & $\begin{array}{l}\text { Let staff members know what is expected of } \\
\text { them }\end{array}$ & .96700 & .99447 \\
\hline & 29 & 23 & $\begin{array}{l}\text { Inform teachers about new ideas he has } \\
\text { come across }\end{array}$ & .96700 & .99447 \\
\hline & 31 & 25 & Explain any default and apologizes & .96700 & .99447 \\
\hline & 10 & 10 & Resist late coming of staff & .87342 & .84569 \\
\hline & 12 & 12 & $\begin{array}{l}\text { Keep tracks of teachers through class } \\
\text { records }\end{array}$ & .90427 & .80201 \\
\hline & 16 & 15 & Are friendly and approachable & .85040 & .81091 \\
\hline & 17 & 16 & Support productivity of teachers & .55040 & .82203 \\
\hline & 4 & 4 & Insist on deadline being met & .90754 & .85875 \\
\hline & 9 & 9 & Programme tight work for teachers & .86201 & .80614 \\
\hline & 18 & 17 & $\begin{array}{l}\text { Consider teachers in assigning } \\
\text { responsibilities }\end{array}$ & .85571 & .99447 \\
\hline & 23 & 20 & Have good rapport with staff & .90427 & .88661 \\
\hline & 26 & 22 & $\begin{array}{l}\text { Provide teachers with suitable materials for } \\
\text { teaching }\end{array}$ & .78818 & .72499 \\
\hline & 35 & 26 & $\begin{array}{l}\text { Show interest in team work for the general } \\
\text { welfare of the school }\end{array}$ & .68988 & .55530 \\
\hline
\end{tabular}




\subsection{Research Question 2}

What is the reliability index of the principals' Leadership Skill Assessment Scale?

The twenty-six items of the LSAS that survived the factor analysis were subjected to a test of internal consistency using the Cronbach alpha. The reliability test was content for each of the emerging four sections of the instrument which represents the four valid factors in the instrument. Summary of the analysis is shown in table $3 i$ - 3iv.

Table 3: Reliability Analysis of the LSAS

Table 3i. Reliability Analysis for Section A: Items of Factor 1

\begin{tabular}{|c|c|c|c|c|c|c|}
\hline \multicolumn{7}{|c|}{$\begin{array}{l}\text { Reliability Analysis - Scale (Alpha) } \\
\text { N of Cases }=262\end{array}$} \\
\hline & Mean & Minimum & Maximum & Range & Max/Min & Variance \\
\hline Item Mean & 2.4333 & 1.9667 & 3.6333 & 1.6667 & 1.8475 & .2364 \\
\hline $\begin{array}{l}\text { Item Variances } \\
\text { Inter-item }\end{array}$ & .8259 & .2402 & 1.2920 & 1.0517 & 5.3780 & .0980 \\
\hline $\begin{array}{l}\text { Covariance } \\
\text { Inter-item }\end{array}$ & .1854 & -.4138 & .7172 & 1.1310 & -1.7333 & .1497 \\
\hline Correlations & $\begin{array}{r}.2123 \\
\text { Alpha }=\end{array}$ & $\begin{array}{r}-.7339 \\
\text { Reliability } \\
7226 \text { Sta }\end{array}$ & $\begin{array}{l}1.0000 \\
\text { efficients } \\
\text { ardized ite }\end{array}$ & $\begin{array}{l}1.7339 \\
\text { ems } \\
\text { pha }=.\end{array}$ & -1.3625 & .2481 \\
\hline
\end{tabular}

Table 3ii. Reliability Analysis for Section B: items of Factor 2

\begin{tabular}{|c|c|c|c|c|c|c|}
\hline \multicolumn{7}{|c|}{$\begin{array}{c}\text { Reliability Analysis - Scale (Alpha) } \\
\text { N of Cases }=262.0\end{array}$} \\
\hline & Mean & Minimum & Maximum & Range & Max/Min & Variance \\
\hline Item Mean & 2.6095 & 2.2000 & 3.6333 & 1.4333 & 1.6515 & .2558 \\
\hline $\begin{array}{l}\text { Item Variances } \\
\text { Inter-item }\end{array}$ & .08962 & .2402 & 1.2747 & 1.0345 & 5.3062 & .1324 \\
\hline $\begin{array}{l}\text { Covariance } \\
\text { Inter-item }\end{array}$ & .0623 & -.4529 & .7172 & 1.1701 & -1.5838 & .1062 \\
\hline Correlations & .0813 & $\begin{array}{l}-.7339 \\
\text { Reliabili }\end{array}$ & $\begin{array}{l}1.0000 \\
\text { oefficients }\end{array}$ & $\begin{array}{l}1.7339 \\
7 \text { items }\end{array}$ & -1.3625 & .1702 \\
\hline
\end{tabular}

Table 3iii: Reliability Analysis for Section C: items of Factor 3

\begin{tabular}{|c|c|c|c|c|c|c|}
\hline & & Reliability & nalysis - Sc & le (Alpha) & & \\
\hline & & $\mathrm{N}$ of & $\operatorname{ses}=$ & 262.0 & & \\
\hline & Mean & Minimum & Maximum & Range & Max/Min & Variance \\
\hline Item Mean & 2.7250 & 2.4333 & 3.1000 & .6667 & 1.2740 & .0988 \\
\hline $\begin{array}{l}\text { Item Variances } \\
\text { Inter-item }\end{array}$ & 1.0261 & .7138 & 1.2195 & .5057 & 1.7085 & .0506 \\
\hline $\begin{array}{l}\text { Covariance } \\
\text { Inter-item }\end{array}$ & .1140 & -.1207 & .6000 & .7207 & -4.9714 & .0571 \\
\hline Correlations & .1249 & $\begin{array}{l}-.1329 \\
\text { Reliabilit } \\
68333\end{array}$ & $\begin{array}{c}.7045 \\
\text { oefficients } \\
\text { idardized i }\end{array}$ & $\begin{array}{l}.8374 \\
4 \text { items } \\
\text { m alpha }=\end{array}$ & -5.3008 & .0789 \\
\hline
\end{tabular}


Table iv: Reliability Analysis for Section D: items of Factor 4

\begin{tabular}{|c|c|c|c|c|c|c|}
\hline & Mean & Minimum & Maximum & $\begin{array}{l}\text { Range } \\
0332\end{array}$ & Max/Min & Variance \\
\hline Item Mean & 2.4611 & 1.9667 & 2.9000 & .9333 & 1.4746 & .0900 \\
\hline $\begin{array}{l}\text { Item Variances } \\
\text { Inter-item }\end{array}$ & .9956 & .5759 & 1.3575 & .7816 & 2.3573 & .0973 \\
\hline $\begin{array}{l}\text { Covariance } \\
\text { Inter-item }\end{array}$ & .1059 & -.3644 & 1.2046 & 1.5690 & -3.3060 & .1613 \\
\hline Correlations & .1014 & $\begin{array}{l}-.3708 \\
\text { Reliabilit } \\
.7166 S\end{array}$ & $\begin{array}{c}.9864 \\
\text { oefficients } \\
\text { dardized it }\end{array}$ & $\begin{array}{l}1.3571 \\
6 \text { items } \\
\mathrm{m} \text { alpha }=\end{array}$ & -2.6604 & .1551 \\
\hline
\end{tabular}

\section{Summary of Result}

Summary of the reliability test presented above indicates that each of the four sections $(A-D)$ of the LSAS has an alpha of $0.72,0.74,0.68$ and 0.72 respectively indicating that each of the four sections of the instrument has high internal consistency.

\section{Discussion of Findings}

The summary of the factor analysis is displayed in Table 1. As shown in the table, 6 factors were extracted. As revealed in the table, only thirty one items had a minimum loading of up to 0.35 on the six factors. Those items are $1,2,3,4,5,6,7,8,9,10,11,12,13,14,15,16,17,18,19,20$, $23,25,26,29,30,31,32,33,34,35$ and 26 . On the other hand five items $(21,22,24,27$ and 28) did not attain the minimum loading of up to 0.35 on any of the six factors. The table also reveals that some factors have fewer than four items loaded on them. They are factors 4 (item 14) and factor 6 (items 33, 34 and 36). Because it is not easy to explain such factors that have fewer than four items loaded on them, those items (items 14, 33, 34 and 36) were also discarded. In all, a total of ten items (items 14, 21, 22, 24, 27, 28, 32, 33, 34 and 36) were dropped as invalid items.

The surviving twenty-six items of the instrument were subjected to a test of reliability using the cronbach alpha. Summary of result of data analysis shown in Table 3 indicate that the reliability indices of the four sections of the instrument are indices of $0.72,0.74,0.68$ and 0.72 . This implies that the instrument is very reliable.

According to Anastasi and Urbina (1997) the concept of reliability underlies the computation of the error of measurement of a single score, whereby we can predict the range of fluctuation likely to occur in a single individual's score as a result of irrelevant or unknown chance factors. Reliability assessment as it concerns this study is to determine the extent to which individual differences in the test scores are attributed to true differences in the characteristics of the principals that responded to the instrument and the extent to which they are attributable to chance error. As revealed by the summary of result in Table 3, whatever test scores obtained with the instrument will be solely attributable to true differences in the leadership skills of the principals.

\section{Conclusion}

Based on the result obtained in this instrumentation research, the researcher concludes that the newly developed and factorially validated leadership skill assessment scale for secondary school principals are both valid and reliable in measuring leadership skills of principals.

\section{Recommendations}

Based on the findings of this study, the researcher recommends that: 
a. Measurement of principals leadership skills should constitute a regular practice of the Post Primary Schools Management Board especially now that a valid and reliable instrument for the exercise has been developed.

b. Researchers in the field of leadership are also advised to use this instrument whenever they come to a situation that requires a clear assessment of principals' leadership skills.

\section{References}

Adesina, S. (1992). Introduction to educational planning. Ile-I fe. University of I fe Press.

Ajiboye, R.A. (1997). Elements of school management. I badan: University Press.

Anastasi, A. and Urbina S. (1997). Psychological testing. New Jersey: Prentice Hall.

Asike (1997). Strategies for resolving conflicts in secondary school administration. Unpublished M.ED Thesis UNN.

Cronbach, L.J. (1951). Coefficient alpha and the internal structure of tests. Psychomettrika http://www. analytictech.co. Retrieved 20/4/2013

Fielder, F.E. (1998). Improving leadership effectiveness. New York: Willey Inc.

Likert, R. (1991). New Patterns of management. New York: McGraw Hill.

Mcshane, S.L. and Vonghnow, M.A. (2000 or 2010 or 2013). Organizational behaviour. Boston: McGraw Hill.

Meredith, G.M. (1969) Dimensions of faculty/faculty of course evaluation Journal of psychology 73,27-32.

Moorhead, G. and Griffin, R.W. (2004). Organizational behaviour: Managing people and organization. New York: Houghton Miffin Company

PPSMB (2004). Guide on promotion/appointment of principals. Enugu PPSMB vol. 1 No 253. 